\title{
Community-based nutrition-sensitive approach to address short-term hunger and undernutrition among primary school children in rural areas in a developing country setting: lessons from North and North-Eastern Uganda
}

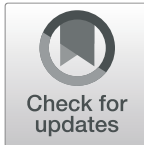

\author{
Samuel Elolu and Duncan Ongeng ${ }^{*}$ (i)
}

\begin{abstract}
Background: Undernutrition in childhood is an important factor that greatly impedes the achievement of full human potential at adulthood. Despite increased enrolment of pupils in primary schools in developing countries, short-term hunger and undernutrition continue to impact negatively on school attendance, retention and education outcomes in economically disadvantaged rural areas. This study examined the feasibility of a community-based participatory action research approach building capacity of rural women food vendors to use local food resources to produce nutritionally enhanced food products for primary school feeding in rural localities in a developing country setting.

Methods: Mixed methods approach incorporating focus group discussions (FGDs) to evaluate parents' and school administrators' perceptions of the community-based approach, participatory experimental improvement of nutritional quality of an energy-based cassava product (gari) involving community women food vendors, and cross-sectional acceptability assessment of improved products among rural primary school children. Qualitative content analysis, one-way analysis of variance and correlation analysis was used to analyse FGD data, compare nutritional profile and consumer sensory profile of different products, and examine associations between sensory attributes and acceptability of the products, respectively.

Results: The approach of using local food resources to produce nutritious products targeting school feeding was strongly recognised by parents, school administrators, teachers and small scale rural women food vendors as an adoptable nutritionsensitive means of addressing short-term hunger among primary school children in rural settings. The action research resulted in a highly accepted nutritionally enhanced product (consisting of cassava, soy and silver fish) exhibiting superior nutritional properties (23.29\% protein, $90.5 \mathrm{~g} / 100 \mathrm{~g}$ calcium, $4.5 \mathrm{~g} / 100 \mathrm{~g}$ zinc, $11.6 \mathrm{~g} / 100 \mathrm{~g}$ iron, $40.40 \mathrm{~g} / 100 \mathrm{~g}$ phosphorus, $61.57 \mathrm{\mu g} / 100 \mathrm{~g}$ vitamin A) compared to the original energy-dominated cassava product (2.18\% Protein, $55.6 \mathrm{~g} / 100 \mathrm{~g}$ calcium, $1.2 \mathrm{~g} / 100 \mathrm{~g}$ zinc, $4.4 \mathrm{~g} / 100 \mathrm{~g}$ iron, $6.6 \mathrm{~g} / 100 \mathrm{~g}$ phosphorus, $11.23 \mu \mathrm{g} / 100 \mathrm{~g}$ vitamin $\mathrm{A})(p<0.05)$. Nutritional computation revealed that serving $120 \mathrm{~g}$ of the new product would suffice to meet $30 \%$ of the recommended dietary allowance for essential nutrients that children should receive from school meals.

(Continued on next page)
\end{abstract}

\footnotetext{
* Correspondence: duncanongeng@hotmail.com

Department of Food Science and Postharvest Technology, Faculty of

Agriculture and Environment, Gulu University, P.O Box 166, Gulu, Uganda
}

C C The Author(s). 2020 Open Access This article is licensed under a Creative Commons Attribution 4.0 International License, which permits use, sharing, adaptation, distribution and reproduction in any medium or format, as long as you give appropriate credit to the original author(s) and the source, provide a link to the Creative Commons licence, and indicate if changes were made. The images or other third party material in this article are included in the article's Creative Commons licence, unless indicated otherwise in a credit line to the material. If material is not included in the article's Creative Commons licence and your intended use is not permitted by statutory regulation or exceeds the permitted use, you will need to obtain permission directly from the copyright holder. To view a copy of this licence, visit http://creativecommons.org/licenses/by/4.0/ The Creative Commons Public Domain Dedication waiver (http://creativecommons.org/publicdomain/zero/1.0/) applies to the data made available in this article, unless otherwise stated in a credit line to the data. 
(Continued from previous page)

Conclusion: Community-level nutrition-sensitive innovation using local foods resources offers the opportunity for rural women food vendors to contribute to addressing short-term hunger and undernutrition challenges in primary schools in economically-disadvantaged localities in developing countries.

Keywords: Community, Nutrition innovation, School feeding, Hunger, Undernutrition

\section{Background}

Inadequate nutrition in childhood has been recognized as one of the greatest impediments to fulfilment of full human potential. It affects over one billion people worldwide with the majority being in developing countries [1]. The central tenet of nutrition in human capacity development is based on the fact that deficiencies of essential nutrients at the childhood stage affect at an individual level, both the mental and physical status, resulting in poor health, poor educability, and poor work performance in adulthood [2]. The number of children enrolled in primary schools in developing countries increased tremendously over the past decades [3]. For instance, in Uganda, following the launch of the Universal Primary Education (UPE) program by the government in 1997, primary school enrolment increased from about three million children in 1996 to 8.3 million in 2009 and as of 2011 most primary-school-age children in the country attended school [4]. However, learner's achievement levels, especially in resource-constrained rural areas such as north and north-eastern regions of the country have often been disappointing. Evidence on outcomes of national examinations over the last two decades indicates that pupils who studied and took examinations from schools in those regions have consistently had very poor performance [5-7]. Several reasons have been advanced to account for such a poor performance outcome. Among them are persistent short-term hunger and poor nutrition that collectively contributes to poor school attendance, inadequate cognitive development, and low educational attainment of the primary school learners.

A number of developing countries have initiated or put in place policies to support school feeding $[8,9]$. Nonetheless, a critical look at existing policy frameworks from various countries in Africa reveals that most of them articulate the rationale and need to provide food to children while at school but are silent on the nutritional quality of the foods. In addition, although many school feeding policies mandate parents and or schools to ensure that children are fed at school, their implementation is not mandatory and the unintended implied consequence is that the better resourced and economically better-off localities easily implement while the under-resourced and economically disadvantaged localities are usually unable to do so. The use of locally available food resources to formulate nutritious food products is believed to be a potential strategy for addressing undernutrition challenges in resourceconstrained localities in developing countries [4]. Indeed, substantial information on community-level research that used locally available food resources to develop elite nutritious composite products for complementary feeding of children in such localities in developing countries exists [10-12]. However, information is scarce on how a similar approach can be used to address short-term hunger and undernutrition experienced by primary school children in similar localities.

A review of literature on existing approaches to challenges of short-term hunger in primary schools in developing countries reveals that community input is largely not taken into account both in terms of development and use of results $[13,14]$. This is notwithstanding the fact that literature within the realm of community development is awash with information to the effect that development outcomes of community-based initiatives are usually enhanced when the community is engaged in the process $[15,16]$. From a nutritional point of view, it is apparent that most school diets in rural areas in developing countries if available are largely dominated by starchy staples (cereals and tubers) that mostly provide energy but are deficient in proteins and micronutrients. This situation calls for investment in easily accessible and adaptable low-cost nutritional innovations based on food resources available within the community to develop local capacity to respond to school feeding challenges in rural areas [4].

North and north-eastern Uganda are among the regions with the least developed rural areas, have the highest number of primary school drop-outs, and very low primary education performance in the country $[7,17]$. These socio-economic characteristics make them a suitable geographical area for the development and testing of nutritional innovations to improve the nutritional welfare of primary school children in economically disadvantaged rural areas. Gari, a granulated cassava food product designed for making instant porridge has a high potential for application as cheap food for school feeding in economically disadvantaged rural areas such as those in the north and north-eastern Uganda. This is because its main raw material, cassava, is widely cultivated and consumed in those regions both as food security and a 
commercial crop. A major limitation associated with gari is that the product is largely energy-based but very low in protein (1.2\%), deficient in essential amino acids and other micronutrients of public health importance such as calcium, iron, zinc, and phosphorous [18]. Therefore, without enrichment with other micronutrient and protein-rich sources, gari remains unsuitable for feeding school children as a base diet.

Therefore, using north and north-eastern Uganda as a case area, and gari as a base product for nutritional improvement, the objective of this study was to examine the feasibility of a community-based participatory action research approach, building the capacity of rural women food vendors to use local food resources to produce nutritionally enhanced products for application in primary school feeding in economically disadvantaged localities in a developing country setting. It is anticipated that local women food vendors would sell nutritious products in schools thus contributing to the nutrition well-being of primary school children as well as to the local economy of the area. In a much wider context, such an approach fits into the current agricultural development frontier which aims at making agribusiness nutritionsensitive [19].

\section{Methods}

\section{Focus group discussion}

Eight Focus group discussions (FGDs) each were conducted among women food vendors, school administrators and teachers, and community members (parents) to: (i) assess the current status of school feeding in rural primary schools; (ii) determine perceptions of use of locally available food resources to produce food products tailored to nutrition needs of school-age children to be sold by local women food vendors in primary schools; and (iii) select food ingredients to be used for improving the nutritional quality of gari. Each focus group discussion had ten (10) members and for each, a set of discussion points covering the three general objectives identified above were interrogated. Discussions with parents and vendors were conducted using the local language while for school administrators and teachers the sessions were held in English.

\section{Development and production of nutritionally improved gari}

Using a participatory community engagement approach, local experience and expertise, and locally fabricated equipment, a method for producing nutritionally enriched gari at the community level was developed together with women food vendors at a farmer field school. The food vendors selected to participate were those who had at least 5 years of selling food in rural primary schools while those who were sick were excluded. On the basis of the FGD, soy and silver fish were selected as candidate resources for use in the nutritional improvement of gari. The selection of soy and silver fish was guided by the fact that they are locally available and are rich sources of protein and micronutrients. Soy is a complete protein source, rich in fat-soluble vitamins (A, D, E \& K) and phosphorus (19), while silver fish is also a good source of proteins, minerals (e.g. calcium and phosphorus), and energy due to the high lipid content [20]. It has a balanced amino acid profile and is particularly rich in methionine and lysine that are deficient in soybean [21]. This implies that a combination of soybeans and silver fish, when used for gari fortification, allows for nutrient complementary benefits. Production of nutritionally improved gari followed three stages. First, raw soybeans and silver fish were separately roasted in a saucepan mounted on a charcoal stove consistent with the village practice in North and NorthEastern Uganda. Roasted materials were separately milled into a fine flour using a locally fabricated grain mill. In the second stage, fermented cassava cakes were produced following the method of Oluwamukomi [22], but with a modification to take care of local conditions. Briefly, fresh cassava tubers were peeled manually with a kitchen knife, washed, and grated using a locally fabricated mechanical grater. Grated cassava was packed in polythene bags and allowed to ferment for $24 \mathrm{~h}$ followed by pressing to dewater the mash. Wet cassava cakes were broken through a grater and pulverized. In the third stage, three gari composite formulae containing various levels of cassava, soybeans and silver fish $(30 \%$ soy: $10 \%$ silver fish: $60 \%$ cassava; $15 \%$ soy: $15 \%$ silver fish: $70 \%$ cassava; and 20 soy: $5 \%$ silver fish: $75 \%$ cassava) were developed using Excel and Harvest Plus Food Composition Table [23]. For each composite formula, roasted soybean and silver fish flour were added at the determined ratios to the cassava mash and toasted to produce the nutritionally enhanced products. Figure 1 shows pictures of gari formulated with various combinations of soy and silver fish.

\section{Analysis of nutritional composition}

Analyses were performed for moisture, dry matter, gross energy, total protein, ash, crude fibre, total carbohydrates, fats, phosphorus, calcium, iron, zinc, and vitamin A. Crude protein was determined using the MicroKjeldahl method as described by Magomya et al. [24]. Ash, gross energy, crude fat, moisture, dry matter, and total carbohydrates were determined according to the AOAC [25]. Vitamin A was quantified following the HPLC method previously described by Mieko et al. [26]. Phosphorus was determined following the vanadomolybdate colourimetry method while calcium, iron, and 


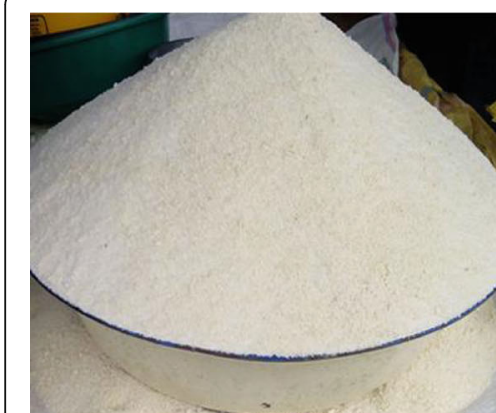

Gari $(100 \%)$ cassava

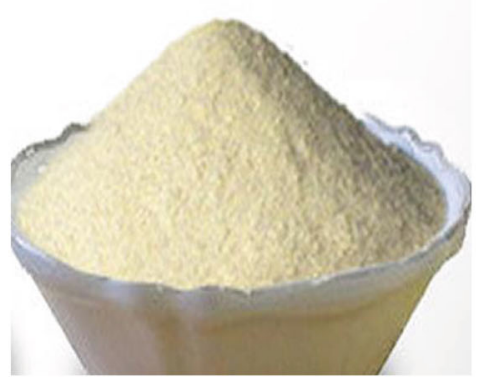

Gari-soy-silver fish (60:30:10)

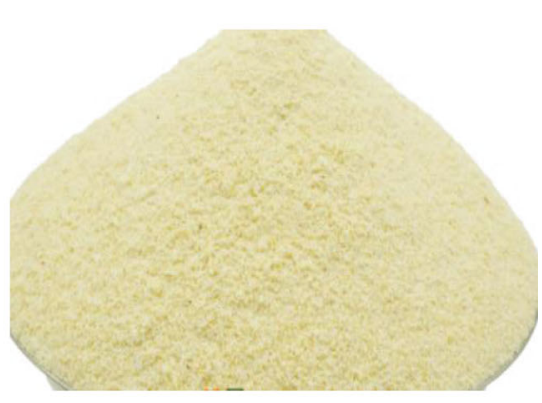

Gari-soy-silver fish (70:15:15)

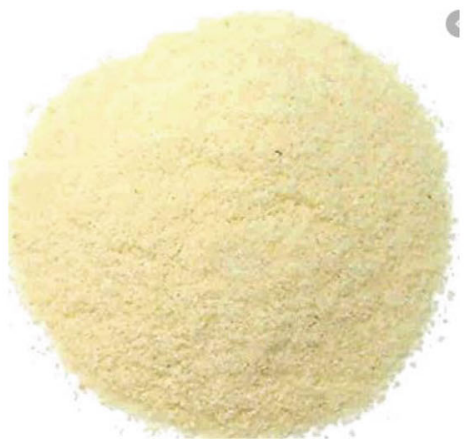

Gari-soy - silver fish (75:20:5)

Fig. 1 Pictures of gari formulated with various combinations of soy and silver fish (source: this study)

zinc were determined using the atomic absorption spectrophotometric method according to the AOAC [25].

\section{Sensory and acceptability evaluation among primary school children}

Sensory evaluation was conducted to compare the level of consumer sensory preference and overall acceptability amongst the various gari products produced. The evaluation was conducted in 12 rural primary schools randomly selected by women food vendors and parents who participated in the FGDs. Consent was sought from parents of all pupils selected to participate in the study. Children with a history of an allergic reaction to soy (based on parent's declaration) were excluded from the study. In addition, those who were sick were also excluded from the study. A total of 180 pupils in the upper primary (aged 10 to 14 years, corresponding with class level four to seven) were included in the evaluation. This is because pupils in this age category are expected to be capable of detecting differences compared to those in lower primary [27]. The samples were reconstituted into instant porridge with hot water according to Oluwamukomi [22]. Briefly, approximately $100 \mathrm{~g}$ of the test sample was added to $500 \mathrm{ml}$ of hot water and stirred constantly to form a smooth thick paste. The samples were coded, randomized, and separately subjected to sensory evaluation by the selected primary school pupils. The pupils were provided with warm water for mouth rinsing before and after every sample tasting to eliminate carryover effects [28]. The extent of liking of colour, texture, aroma, taste, and overall acceptability of the products was evaluated on a 5-point hedonic scale (ranging from $1=$ poor to $5=$ very good). This scale was purposely chosen for the study because it typically gives a higher response rate compared to other longer scales [29]. Besides, longer scales would be unsuitable for the primary school children who are non-experienced in sensory evaluation.

\section{Data analysis}

Data from FGDs were analysed using mixed method content analysis [30]. This enabled the generation of a detailed description of qualitative information based on group consensus to understand the context of respondents' perspectives towards school feeding. Essentially, the main themes emerging from different FDGs were identified and key findings summarised in a tabular form. In the case of nutritional improvement, One Way Analysis of Variance (ANOVA) was performed to compare the proximate composition, micronutrient contents, and scores for sensory preference and overall acceptability amongst various gari products. Correlation analysis was used to examine the association between sensory attributes (colour, aroma, texture, and taste) and overall 
consumer acceptability of the products. All statistical analyses were performed using SPSS version 2.0 while the level of statistical significance was fixed at $5 \%$.

\section{Results}

Perceptions of women food vendors, school

administrators, teachers, and parents

Results from the FGDs, summarised in (Table 1) indicate that parents, school administrators, and teachers strongly appreciated the need for school feeding. However, they also pointed out that such programs are largely lacking and in cases where they exist, it is not mandatory, thus the majority of pupils in the rural primary schools actually go through the school hours without any food. While the need to address the food needs of primary school children was dominantly pointed out, a specific understanding of nutrition with respect to limiting nutrients such as proteins and micronutrients did not emerge clearly from the parents as well as school administrators and teachers. In terms of bottlenecks, parents were largely constrained by the poor economic conditions in the area, lack of proper guidelines and laws to govern school feeding. Women food vendors were constrained by the lack of knowledge on food processing and nutrition needs of school children, lack of coordination with schools, and financial challenges. School administrators revealed that existing school feeding programs were initiatives of the schools, but their designs largely excluded parents' participation. This notwithstanding, parents and women food vendors expressed a strong desire to cooperate with partners such as Universities and other institutions to design and

Table 1 Rural community perspectives on the status of school feeding

\begin{tabular}{|c|c|}
\hline Themes of Discussion & Overall FGD findings \\
\hline Overall status of school feeding & $\begin{array}{l}\text { School-wide feeding programs are largely unavailable. Only parents who can } \\
\text { afford to pack food or pay extra fees for feeding can have their children eat at } \\
\text { school (these are very few). Previous school feeding interventions sponsored by } \\
\text { Non-governmental organisations (NGOs) closed when projects ended. Nutritional } \\
\text { quality of food is usually not taken into consideration in school feeding program } \\
\text { designs thus meals are largely limited to corn-based porridge for breakfast. }\end{array}$ \\
\hline
\end{tabular}

The necessity of school feeding

Constraints to school feeding

Possible local community alternatives to school feeding

Knowledge of nutritional needs of school children and the improvement of local food resources

Community-level partnerships for school feeding

Willingness to work with partners in the design and testing innovations on school feeding based on local food resources
There is consensus over the need to provide food to school-going children. It is strongly believed that providing meals will keep pupils at school and help them study better. The need for school food to meet the nutritional needs of children is well appreciated (considered important). However, nutritious food recipes tailored for application in school feeding in rural areas are largely unavailable.

Resources are inadequate (parents are unable to access adequate food at home as well as for school feeding) thus packed lunch is hard to afford. Foods previously provided and promoted by NGOs are expensive for parents while there are no clear guidelines and laws in place to enforce mandatory school feeding in rural schools.

School gardening would be suitable since most schools in rural areas have farmland. Parents and school administration can also engage to produce food for school feeding. Local staple foods can be mobilised for school feeding from parents.

There is limited understanding of the nutritional quality of foods (current food provision focuses on supplying energy) by parents and women food vendors while teachers are aware of the nutrition needs of school children. No specific technologies are known or practised to improve the nutritional quality of local staple foods at community levels or in rural schools. Local community members lack knowledge on how to improve the nutritional quality of local foods.

Previously some NGOs such as World food program (WFP) and World Vision International have sponsored school feeding programs but with limited participation of the community. Thus NGO-led programs did not continue after NGO funding ceased. Existing school feeding initiatives are school-led, with limited involvement of parents and the general community in their design. The notion of active participation of the community in producing and processing food for school feeding programs is highly appreciated and is believed to ensure program ownership and sustainability.

Perceived as a good opportunity to gain knowledge and skills in nutrition interventions for local application. Use of local food resources would make school feeding more affordable for parents and rural schools. Building capacity in food processing would be a good business opportunity for the small scale women food processors and vendors to address the nutrition needs of school children. 
test innovative approaches for school feeding. Specifically, parents viewed the proposed use of local food resources as a cheaper alternative to traditionally suggested school provisioning means that require parents to pay extra money for feeding. Generally, the idea of using cassava and other local food resources such as soy and silver fish as well as empowering local women food vendors as producers of nutritious foods for application in school feeding was well-received by all stakeholders that participated in the FGDs.

\section{Nutritional profile of the improved products}

Proximate composition of the improved products in comparison with the original gari is presented in Table 2. Generally, the addition of soy and silver fish significantly improved the nutritional profile of gari. The formulations containing combinations of soy and silver fish had significantly higher levels of proteins, dietary fibre and fat $(p<0.05)$. Specifically, the protein content increased from $2.18 \%$ in pure gari to $23.29 \%$ in the gari-soy-silver fish composite while dietary fibre content increased from 5.63 to $10.53 \%$. The fat content increased from 0.41 to $8.78 \%$ with increased soy and silver fish proportions leading to higher composite fat levels. Similarly, the addition of soy and silver fish significantly increased the ash content of gari $(p<0.05)$ from 1.41 to $4.22 \%$. The rise in the level of ash increased with higher levels of soy and silver fish inclusion. On the other hand, the incorporation of soy and silver fish into gari significantly reduced the moisture $(p<0.05)$ and total carbohydrate content $(p<0.05)$ by about 41 and $42 \%$, respectively. The reduction in carbohydrate content increased as the combined proportion of soy and silver fish in the formulation increased. Despite the reduction in carbohydrate content, gross energy increased by $22 \%$ per unit as a result of the addition of soy and silver fish.

The contents of calcium, iron, zinc, phosphorus and vitamin $\mathrm{A}$ in the improved products in comparison to the original gari are presented in Table 3 . In general, the inclusion of soy and silver fish significantly increased the mineral and vitamin A content of gari $(p<0.05)$. In all cases, the level of micronutrients in gari increased with increase in the proportion of soy and silver fish in the formulae. Specifically, the contents of calcium, iron, zinc, phosphorus, and vitamin A increased from 55.6 to 90.5 , 4.4 to $11.6,1.2$ to $4.5,6.6$ to $40 \mathrm{~g} / 100 \mathrm{~g}$ and 11.23 to $61.57 \mu \mathrm{g} / 100 \mathrm{~g}$, respectively following the addition of soy and silver fish.

\section{Consumer sensory preference and overall acceptability}

Results of ratings of consumer sensory preference and overall acceptability of the improved products in comparison to the original gari are presented in Table 4 . Generally, ratings for all the sensory parameters of formulations containing soy and silver fish were statistically similar to that of the original gari. Ratings for all the parameters were within acceptable limits with exception of the deviation indicating that pure gari $(100 \%$ cassava) was best preferred in terms of colour. Thus, overall acceptability ratings were generally identical except for the formula containing $20 \%$ soy and $5 \%$ silver fish which was rated higher than the formulae containing other levels of soy and silver fish.

All the sensory properties had a strong positive correlation with overall acceptability irrespective of the formulation type (Table 5). In terms of magnitude, product taste had the strongest level of correlation with overall acceptability followed by aroma, texture and colour in decreasing order. However, despite the strong association with overall acceptability, none of the relationships was significant except in the case of original gari for which colour, texture and aroma significantly influenced overall acceptability. On the basis of the overall acceptability assessment, children chose the product with a combination of $75 \%$ cassava, $20 \%$ soy and $5 \%$ silver fish as the most preferred product and was consistent with the overall acceptability rating.

\section{Discussion}

The role of school feeding in tackling short-term hunger and undernutrition is critical in contributing to the positive outcome of education among children [31, 32]. Several approaches to school feeding exist $[8,33]$. However, in the context of resource-constrained agrarian rural

Table 2 Proximate composition of gari formulated with various proportions of soy and silver fish

\begin{tabular}{llllllll}
\hline $\begin{array}{l}\text { Composite } \\
\text { Formulae }\end{array}$ & $\begin{array}{l}\text { Crude Protein } \\
(\%)\end{array}$ & $\begin{array}{l}\text { Total CHO } \\
(\%)\end{array}$ & Ash (\%) & $\begin{array}{l}\text { Dietary Fibre } \\
(\%)\end{array}$ & $\begin{array}{l}\text { Moisture Content } \\
(\%)\end{array}$ & $\begin{array}{l}\text { Fat content } \\
(\%)\end{array}$ & $\begin{array}{l}\text { Gross energy } \\
\text { (Kcal/g) }\end{array}$ \\
\hline Control (100:0) & & & & & & & \\
& $2.18 \pm 0.00^{\mathbf{a}}$ & $87.02 \pm 1.86^{\mathbf{d}}$ & $1.41 \pm 0.02^{\mathbf{a}}$ & $5.63 \pm 0.17^{\mathbf{a b}}$ & $8.66 \pm 0.13^{\mathbf{d}}$ & $0.41 \pm 0.56^{\mathrm{a}}$ & $3.94 \pm 0.03^{\mathbf{a}}$ \\
& & & & & & \\
& & & & & & \\
Gari-Soy-silver fish & & & & & & & \\
$\mathbf{6 0 : 3 0 : 1 0}$ & $23.29 \pm 0.42^{\mathbf{d}}$ & $50.60 \pm 1.25^{\mathbf{a}}$ & $4.22 \pm 0.08^{\mathbf{c}}$ & $10.53 \pm 0.62^{\mathbf{d}}$ & $5.01 \pm 0.07^{\mathbf{a}}$ & $8.78 \pm 0.16^{\mathbf{c}}$ & $4.81 \pm 0.01^{\mathbf{c}}$ \\
$\mathbf{7 0 : 1 5 : 1 5}$ & $19.84 \pm 0.39^{\mathbf{c}}$ & $72.25 \pm 1.84^{\mathbf{b c}}$ & $3.91 \pm 0.11^{\mathbf{c}}$ & $6.88 \pm 0.64^{\mathbf{b c}}$ & $8.53 \pm 0.12^{\mathbf{c d}}$ & $5.64 \pm 0.04^{\mathrm{b}}$ & $4.34 \pm 0.02^{\mathbf{b}}$ \\
$\mathbf{7 5 : 2 0 : 5}$ & $15.10 \pm 0.17^{\mathbf{b}}$ & $72.39 \pm 2.54^{\mathbf{b c}}$ & $3.11 \pm 0.00^{\mathbf{b}}$ & $7.99 \pm 0.30^{\mathbf{c}}$ & $7.83 \pm 0.11^{\mathbf{b c}}$ & $5.69 \pm 0.09^{\mathrm{b}}$ & $4.38 \pm 0.01^{\mathbf{b}}$ \\
\hline
\end{tabular}

Values are means \pm SD of three independent determinations. Values with different superscripts within the same column are significantly different $(P \leq 0.05)$. 
Table 3 Mineral content of gari formulated with different proportions of soy and mukene

\begin{tabular}{llllll}
\hline Composite Formulae & Calcium $(\mathbf{g} / \mathbf{1 0 0} \mathbf{g})$ & Iron $(\mathbf{g} / \mathbf{1 0 0} \mathbf{g})$ & Phosphorus $(\mathbf{g} / \mathbf{1 0 0} \mathbf{g})$ & Zinc $(\mathbf{g} / \mathbf{1 0 0} \mathbf{g})$ & Vitamin A $(\boldsymbol{\mu g} / \mathbf{1 0 0} \mathbf{g})$ \\
\hline $\begin{array}{l}\text { Control }(100: 0) \\
\text { Gari-soy-silver fish }\end{array}$ & $55.6 \pm 0.020^{\mathbf{a}}$ & $4.40 \pm 0.000^{\mathbf{a}}$ & $6.60 \pm 0.019^{\mathbf{a}}$ & $1.20 \pm 0.001^{\mathbf{a}}$ & $11.23 \pm 0.59^{\mathbf{a}}$ \\
60:30:10 & $90.5 \pm 0.020^{\mathbf{c d}}$ & $11.60 \pm 0.000^{\mathbf{c}}$ & $40.40 \pm 0.009^{\mathbf{c}}$ & $4.50 \pm 0.002^{\mathbf{d}}$ & $61.57 \pm 0.59^{\mathbf{d}}$ \\
$70: 15: 15$ & $86.7 \pm 0.020^{\mathbf{c}}$ & $10.40 \pm 0.000^{\mathbf{b}}$ & $39.50 \pm 0.009^{\mathbf{c}}$ & $3.90 \pm 0.001^{\mathbf{c}}$ & $54.67 \pm 1.26^{\mathbf{c}}$ \\
$75: 20: 5$ & $83.3 \pm 0.020^{\mathbf{b}}$ & $9.80 \pm 0.000^{\mathbf{b}}$ & $22.70 \pm 0.009^{\mathbf{b}}$ & $2.30 \pm 0.002^{\mathbf{b}}$ & $41.79 \pm 1.76^{\mathbf{b}}$ \\
\hline
\end{tabular}

Values are means + SD of three independent determinations. Values with different superscripts within the same column are significantly different $(P \leq 0.05)$.

settings, developing linkages between school feeding and local agricultural development is generally viewed as a potential strategy for effecting school feeding programs. However, this strategy has not been well exploited in several developing countries [33, 34]. In this study, north and north-eastern Uganda was used as a microcosm for economically disadvantaged rural areas typical of a developing country setting. The fact that parents, rural women food vendors, school teachers and administrators had a strong positive perception towards commerciallyoriented community-based school feeding approach suggests that the approach, whereas designed to address school feeding challenge, presents the opportunity to support the agricultural economy of the areas within the vicinity of the schools. One peculiar characteristic of this study was the participatory action research approach to the design, development and testing of the new nutritious products. The fact that stakeholders agreed and cooperated suggests that the approach offers a strong opportunity for local people to provide local solutions to school feeding challenge in economically disadvantaged rural areas. This is because the food resources used in the formulation of the nutritious product are locally available in the community.

Whereas rural women food vendors were enthusiastic about producing the developed nutritious products to support school feeding, it was apparent that they lacked technical knowledge and skills on how to formulate and produce nutritious products targeting nutrition needs of school children. This finding provides evidence to the effect that lack of sufficient knowledge on nutrition is an important factor that impedes judicial use of locally available food resources to address nutrition-related development challenges among economically disadvantaged agrarian communities in developing countries. By inference, therefore, it becomes apparent that building local capacity in nutrition-sensitive food processing linked to end-users of the products as illustrated in this study provides the opportunity for local investment in agri-food value addition to tackling local nutritional challenges.

Considering that cassava, the main raw material used in the production of the nutritious product is largely energy based [35], the introduction of soy and silver fish was meant to address the issue of deficiency of protein and micronutrients in cassava. It is important to appreciate that lack of inclusion of animal source foods in the diet is one of the factors that negatively affect the intake of bioavailable proteins and mineral micronutrients among economically disadvantaged communities in developing countries [36,37]. This is because proteins and minerals from animal source foods are superior to those from plant sources because of low bio-availability from plant sources due to the presence of anti-nutritional factors $[38,39]$. Therefore, it has been recommended that plant foods should be consumed together with animal foods to improve the bio-availability of proteins and minerals from the latter food group [38]. Additional advantages that formulations containing both soy and silver fish have are the amino acid complementarity benefit. For instance, soy protein is limited in sulphur amino acids while silver fish, an animal source protein is richer in amino acids methionine and lysine [21]. Additionally, soy contains significant amounts of bioactive compounds that are thought to offer protection against cardiovascular diseases and are believed to enhance

Table 4 Scores on sensory attributes and acceptability of gari by primary school pupils

\begin{tabular}{llllll}
\hline Composite Formulae & Ratings for: Colour & Aroma & Texture & Taste & Overall acceptability \\
\hline Control (100:0) & $3.63 \pm 1.37^{\mathbf{b}}$ & $3.37 \pm 1.27^{\mathbf{d}}$ & $2.59 \pm 3.09^{\mathbf{a}}$ & $3.27 \pm 3.09^{\mathbf{c}}$ & $3.10 \pm 1.30^{\mathbf{a b}}$ \\
Gari-soy-silver fish & & & & & \\
60:30:10 & $2.70 \pm 1.44^{\mathbf{a}}$ & $2.87 \pm 1.38^{\mathbf{b c}}$ & $3.02 \pm 1.20^{\mathbf{b}}$ & $2.93 \pm 1.36^{\mathbf{a b c}}$ & $2.80 \pm 1.30^{\mathbf{a}}$ \\
$70: 15: 15$ & $3.02 \pm 1.37^{\mathbf{a}}$ & $2.68 \pm 1.25^{\mathbf{a b}}$ & $3.33 \pm 1.24^{\mathbf{b}}$ & $2.85 \pm 1.37^{\mathbf{a b}}$ & $2.89 \pm 1.26^{\mathbf{a}}$ \\
$75: 20: 5$ & $3.02 \pm 1.34^{\mathbf{a}}$ & $3.12 \pm 1.27^{\mathbf{c d}}$ & $3.20 \pm 1.18^{\mathbf{b}}$ & $3.13 \pm 1.33^{\mathbf{a b c}}$ & $3.25 \pm 1.30^{\mathbf{b}}$ \\
\hline
\end{tabular}

Values are means \pm SD of scores by 180 pupils. Values with different superscripts within the same column are significantly different $(P \leq 0.05)$. Scores are based on a 5-point hedonic scale. 
Table 5 Influence of sensory properties on overall acceptability of composites

\begin{tabular}{lllll}
\hline Sensory Attribute & Gari (100:0) & Gari-soy-silver fish (60:30:10) & Gari-soy-silver fish (70:15:15) & Gari-soy-silver fish (75:20:5) \\
\hline Colour & 3.426 & 2.700 & 3.016 & 3.017 \\
Acceptability & 3.100 & 2.806 & 2.892 & 3.252 \\
Correlation & $0.301^{\mathrm{a}}$ & $0.298^{\mathrm{a}}$ & $0.190^{\mathrm{a}}$ & 0.132 \\
P-value & 0.016 & 0.499 & 0.415 & 0.131 \\
Texture & 2.595 & 3.025 & 3.333 & 3.175 \\
Acceptability & 3.100 & 2.806 & 2.892 & 3.252 \\
Correlation & $0.330^{\mathrm{a}}$ & 0.137 & $0.221^{\mathrm{a}}$ & $0.398^{\mathrm{a}}$ \\
P-value & 0.001 & 0.131 & 0.146 & 0.501 \\
Aroma & 3.369 & 2.867 & 2.680 & 3.118 \\
Acceptability & 3.100 & 2.806 & 2.892 & 3.252 \\
Correlation & $0.421^{\mathrm{a}}$ & $0.220^{\mathrm{a}}$ & $0.203^{\mathrm{a}}$ & $0.299^{\mathrm{a}}$ \\
P-value & 0.009 & 0.653 & 0.211 & 0.338 \\
Taste & 3.272 & 2.933 & 2.857 & 3.125 \\
Acceptability & 3.100 & 2.802 & 2.892 & 3.252 \\
Correlation & $0.300^{\mathrm{a}}$ & $0.631^{\mathrm{a}}$ & $0.628^{\mathrm{a}}$ & $0.779^{\mathrm{a}}$ \\
P-value & 0.592 & 0.204 & 0.685 & 0.145 \\
\hline
\end{tabular}

Values with ${ }^{a}$ are statistically significant at $5 \%$ level of confidence.

brain and nerve functions [40]. This indicates the health benefits that gari containing soy would confer to school children. Whereas non-communicable diseases are more prevalent in ageing populations but less in children [41], it is probable that protection right from childhood age could reduce the chances of the problem occurring at old age. Thus, the use of soy and silver fish in the new cassava-based product does not only result in a nutritionally superior product but may also enhance the intake of bioavailable nutrients by school children as well as conferring other non-nutritional health benefits to them.

Appropriate dietary quality is an important factor that needs to be considered if school meals are to be in tandem with the recommended nutrient intake levels [9, 42]. A review of policy documents indicates peculiarity in nutritional standards for school meals among countries. For instance, many countries in South America have specifications for school meals set in the range of $20-30 \%$ of the daily nutrient requirements, while in Africa, specifications available for South Africa are set at $30 \%[9,14]$. However, information on the proportion of daily nutrient needs that school children should derive from school meals is largely lacking for the vast majority of developing countries including Uganda. Thus, basing on the South Africa specification, nutritional calculation reveals that serving $150 \mathrm{~g}$ of the new product would be sufficient to provide the total recommended daily protein requirement while $45 \mathrm{~g}$ would provide at least $30 \%$ of daily protein needs for children that school meals should provide. A similar calculation reveals that serving about $120 \mathrm{~g}$ of the enriched product would be sufficient for primary school children to meet $30 \%$ of the daily requirements for energy, as well as the recommended daily dietary allowance for calcium, iron, zinc and vitamin A. Nonetheless, a follow-up study focusing on the effect of the nutritious cassava product on nutrition outcomes among primary school children would provide more evidence on the potential of the product. Although the nutritional focus of product development reported in this study was on improving access to proteins and micronutrients of public health importance, it was also associated with changes in other important nutritional properties (such as carbohydrates, fat and energy content) of gari (Table 2). However, the most significant meriting attention was the increase in the fat content of gari. Considering the rich fatty acid profile of silver fish and soy, the increase in the fat content of the formulations would provide the opportunity for increased intake of essential fatty acids and omega-3 fatty acids in particular among school children. This is important considering that omega-3 fatty acids are important for cardiovascular health [43].

Consumer acceptability of food depends on a number on several factors including product sensory properties, familiarity, attractiveness and traditional values [44]. The fact that stakeholders (school administrators and teachers, parents and women food vendors) selected the food resources that constituted the new product suggests that issues of familiarity and tradition were favourable. Indeed, the high degree of enthusiasm with which women food vendors and primary school children 
participated in the study provides additional indications. As observed in previous studies [35, 45], in the current study, formulations containing higher proportions of soy had higher sensory ratings and were better preferred by the school children. This could be attributed to the pleasant aroma of roasted soy [35]. To the contrary, lower sensory scores were recorded for formulations with higher proportions of silver fish in terms of aroma and overall acceptability are likely due to the fishy odour from silver fish. This negative sensorial appeal is not peculiar to the product developed in this study. It was also encountered in fish fortified dairy products developed before [46]. Nonetheless, despite variations in the rating of sensory parameters among different formulations, the ratings for overall consumer acceptability were generally similar. This indicates that overall, improvement in the nutritional quality of gari through the incorporation of soy and silver fish at levels used in this study did not exert substantial negative sensorial deviations. Nonetheless, future studies should evaluate sensory stability of the nutritious products during storage to provide indications on the length of time they can remain acceptable.

The fact that there was a strong positive correlation between sensory properties of pure cassava-based gari and overall acceptance but not for other formulations containing soy and silver fish, suggests that overall acceptability of gari formulations containing soy and silver fish may be dependent on other non-sensory factors. This results also indicate that acceptability based on sensory ratings is not in tandem with the selection of better nutritious products. This observation further confirms the well-known fact that sensorial appeal overrides nutrition quality in determining food selection [47]. The nutrition-sensitive innovation presented in this paper successfully passed the development stage and is now ready for uptake by rural women food vendors and primary schools. However, due to the commercial-oriented nature of the product, its success in the school feeding market would largely depend on its affordability. A major limitation of this study however is that break-even analysis was not conducted and as such unit price and whether the product would be affordable is still unknown. Considering the significance of price in determining consumer willingness to pay for any commodity [48], future studies should therefore look at the economics of the nutritious cassava-based product in the market environment of rural primary schools. This analysis would be important because lack of resources was identified (during FGD) as one of the key impediments to parents' support towards the school feeding programme.

\section{Conclusion}

This study has demonstrated the potential of community-based action research in nutrition-sensitive value addition using local food resources to build local capacity to respond to short-term hunger and undernutrition among primary school children in economically disadvantaged rural areas in developing countries. Besides providing a local solution to the nutritional challenge faced by children in rural schools and offering an entrepreneurial opportunity to rural women food vendors, the study illustrates that community members are enthusiastic about participating in producing local research solutions to local challenges such as undernutrition and short-term hunger experienced by their children in rural primary schools. This approach offers an alternative means to the industrially fortified products that children in rural schools are usually unable to access.

\section{Abbreviations}

FGD: Focus group discussion; UPE: Universal Primary Education; AOAC: Association of Official Analytical Chemists; HPLC: High Performance Liquid Chromatography; ANOVA: Analysis of Variance; SPSS: Statistical Package for the Social Sciences; NGO: Non-Governmental Organisation; WFP: World Food Program; GUREC: Gulu University Research Ethics Committee; RUFORUM: Regional Universities Forum For Capacity Building in Agriculture

\section{Acknowledgements}

We express our gratitude to RUFORUM, Women food vendors in North and North Eastern Uganda, Primary school teachers and pupils in the 12 schools in North and North Eastern Uganda, who participated in the study.

\section{Authors' contributions}

SE participated in study design, collected data and drafted the manuscript. DO designed the study, reviewed literature and revised the manuscript. All authors have read and approved the manuscript.

\section{Funding}

This study was supported by a graduate research grant from the Regional Universities Forum for Capacity Building in Agriculture (RUFORUM). Grant Number RU/2014/GRG-098. However, the funding body had no role in the study design, collection, and analysis, interpretation of data or in the writing of the manuscript.

\section{Availability of data and materials}

All relevant data from which conclusions of the manuscript have been drawn are presented in the paper.

\section{Ethics approval and consent to participate}

The study was approved by the Gulu University Research Ethics committee (GUREC-048-15). Participation in the study was voluntary and with full consent of respondents. For pupils selected to participate in the study, their parents were contacted and parental consent secured before their

participation. In all cases, consent was written.

\section{Consent for publication}

Not applicable.

\section{Competing interests}

The authors declare no competing interests.

Received: 30 August 2020 Accepted: 18 November 2020

Published online: 14 December 2020

\section{References}

1. Wang D, Fawzi WW. Impacts of school feeding on educational and health outcomes of school-age children and adolescents in low and middleincome countries: protocol for a systematic review and meta-analysis. Syst Rev. 2020;9(1):4-11. 
2. Alderman $\mathrm{H}$, Hoddinott J, Kinsey B. Long term consequences of early childhood malnutrition. Oxf Econ Pap. 2006;58(3):450-74.

3. Bundy, DAP, de Silva N, Horton S, Jamison DT, Patton GC. Re-imagining school feeding: a high-return investment in human capital and local economies. World Bank. 2019.

4. Korugyendo PL, Benson T. Food-for-education programs: lessons for Uganda. Uganda strategy support program, policy note no.13. Int Food Pol Res Inst. 2011.

5. Higgins K. Regional inequality and primary education in Northern Uganda, policy brief no.2. Overseas Dev Inst. 2009.

6. JAICA \& IDCJ. Basic Education Sector Analysis Report, Uganda; 2012. p. 1-105. Available from: www.jica.go.jp.

7. Poro SG, Yiga AP, Enon JC, Mwosi F, Eton M. Teacher competence and performance in primary schools in Nwoya District, Northern Uganda. Int J Adv Educ Res Int. 2019:4(1):3-8.

8. Gelli A, Masset E, Folson G, Kusi A, Arhinful DK, Asante F, et al. Evaluation of alternative school feeding models on nutrition, education, agriculture and other social outcomes in Ghana: Rationale, randomised design and baseline data. Trials. 2016;17(1):37. Available from:. https://doi.org/10.1186/s13063-015-1116-0.

9. Food and Agriculture Organization and World Health Organization. Nutrition guidelines and standards for school meals; 2019. p. 1-110.

10. Ahoya B, Kavle JA, Straubinger S, Gathi CM. Accelerating progress for complementary feeding in Kenya: key government actions and the way forward. Matern Child Nutr. 2019;15(S1):1-8.

11. Phuka. Complementary feeding with fortified spread and incidence of severe stunting in 6- to 18-month-old rural Malawians. Arch Pediatr Adolesc Med. 2008;162(10):942.

12. Fabrizio CS, van Liere M, Pelto G. Identifying determinants of effective complementary feeding behaviour change interventions in developing countries. Matern Child Nutr. 2014;10(4):575-92.

13. Potts MJ, Nagujja S. A review of agriculture and health policies in Uganda with implications for the dissemination of biofortified crops, working paper no.1. Harvest. 2007.

14. Aliyar R, Gelli A, Hamdani SH. A review of nutritional guidelines and menu compositions for school feeding programs in 12 countries. Front Public Heal. 2015;3(August):1-13.

15. Ashe LM, Sonnino R. At the crossroads: new paradigms of food security, public health nutrition and school food. Public Health Nutr. 2013;16(06): 1020-7 Available from: http://www.journals.cambridge.org/abstract_S136 8980012004326

16. Lubogo D, Orach CG. Stakeholder perceptions of research options to improve nutritional status in Uganda. BMC Nutr. 2016;2(1):1-11. Available from:. https://doi.org/10.1186/s40795-016-0067-5.

17. Nabugoomu J. School dropout in rural Uganda: stakeholder perceptions on contributing factors and solutions. Educ J. 2019;8(5):185.

18. Montagnac JA, Davis CR, Tanumihardjo SA. Nutritional value of cassava for use as a staple food and recent advances for improvement. Compr Rev Food Sci Food Saf. 2009;8(2009):181-94.

19. Gillespie S, van den Bold M. Agriculture, food systems, and nutrition: meeting the challenge. Glob Challenges. 2017;1(3):1600002

20. Awuor L, Kirwa E, Jackim F, Nyambura B. Proximate composition of Rastrineobola argentea ( Dagaa ) of Lake Victoria-Kenya. Afr J Biochem Res. 2014;8(1):1-6

21. Toppe J, Albrektsen S, Hope B, Aksnes A. Chemical composition, mineral content and amino acid and lipid profiles in bones from various fish species. Comp Biochem Physiol. 2007;146(B):395-401.

22. Oluwamukomi M. Chemical And Sensory Properties Of Gari Enriched With Sesame Seed Flour ( Sesamum indicum L .). FUTA J Res Sci. 2015;11(1):123-31.

23. Hotz C, Lubowa A, Sison C, Moursi M, Loechl C. A Food Composition Table for Central and Eastern Uganda. HarvestPlus Technical Monograph 9 (B); 2012. p. 1-36.

24. Magomya AM, Kubmarawa D, Ndahi JA, Yebpella GG. Determination of plant proteins via the Kjeldahl method and amino acid analysis : a comparative study. Int J Sci Technol Res. 2014;3(4):68-72.

25. Adepoju OT, Adekola YG, Mustapha SO, Ogunola SI. Effect of processing methods on nutrient retention and contribution of cassava (Manihot spp) to nutrient intake of Nigerian consumers. African J Food, Agric Nutr Dev. 2010;10(2):2099-111.

26. Mieko K, Koborib CN. DBR-A and PN. Screening and HPLC methods for carotenoids in sweetpotato, cassava and maize for plant breeding trials. J Food Chem. 2007;100:1734-46.
27. Nicklaus S. Sensory testing in new product development: Working with children. Rapid Sensory Profiling Techniques and Related Methods: Applications in New Product Development and Consumer Research. Woodhead Publishing Limited; 2015. 473-484. Available from: https://doi. org/10.1533/9781782422587.4.473.

28. Emmanuel-Ikpeme CA, Eneji UE. Storage Stability and Sensory Evaluation of Taro Chips Fried in Palm Oil , Palm Olein Oil , Groundnut Oil , Soybean Oil and Their Blends. Pakistan J Nutr. 2007;6(6):570-5.

29. Dawes J. Do data characteristics change according to the number of scale points used? An experiment using 5-point, 7-point and 10-point scales. Int J Mark Res. 2008:50(1):61-77 Available from: http://www.scopus.com/inward/ record.url?eid=2-s2.0-39149141861\&partnerlD=40\&md5=c3d7b9ea4785d3 $75462 \mathrm{~d} 4016 \mathrm{~d} 154 \mathrm{e} 476$

30. Kansiime MK, Watiti J, Mchana A, Jumah R, Musebe R, Rware H. Achieving scale of farmer reach with improved common bean technologies: the role of village-based advisors. J Agric Educ Ext. 2018;24(3):215-32.

31. Jomaa LH, Mcdonnell E, Probart C. School feeding programs in developing countries : impacts on children 's health and educational outcomes. Nutr Rev. 2011;69(2):83-98.

32. Ayogu RNB, Eme PE, Anyaegbu VC, Ene-Obong HN, Amazigo UV. Nutritional value of school meals and their contributions to energy and nutrient intakes of rural school children in Enugu and Anambra states. Nigeria BMC Nutr. 2018;4(1):1-11.

33. Sumberg J, Sabates-wheeler R. Linking agricultural development to school feeding in sub-Saharan Africa : theoretical perspectives. Food Policy. 2011; 3(2011):1-9. Available from:. https://doi.org/10.1016/j.foodpol.2011.03.001.

34. Masset E, Gelli A. Improving community development by linking agriculture. Nutrition and education. Design of a randomised field experiment of "home grown" school feeding in Mali, trials, 14(55). Trials. 2013;14(55):1745-6215.

35. Eke UB, Owalude SO, Usman LA. Enrichment of a cassava meal ( Gari ) with Soyabean protein extract. Av Nat Apllied Sci. 2008;2(2):60-2.

36. Herman EM. The challenge to meet global need for protein sources for animal production. In: The Institute on Science for Global Policy; 2012. p. 1-3.

37. Schönfeldt HC, Hall NG. Dietary protein quality and malnutrition in Africa. $\mathrm{Br}$ J Nutr. 2012;108(SUPPL. 2):867-76.

38. Hoffman JR, Falvo MJ. Protein - which is best?, Review article. J Sport Sci Med. 2004;2005:118-30.

39. Bolanho BC, Del A, Beléia P. Bioactive compounds and antioxidant potential of soy products. Alim Nutr, Araraquara. 2011;22(4):539-46.

40. Messina M. Soy and health update: Evaluation of the clinical and epidemiologic literature. Nutrients. 2016;8(12):754.

41. Maimela E, Alberts M, Modjadji SEP, Choma SSR, Dikotope SA, Ntuli TS, et al. The prevalence and determinants of chronic non-communicable disease risk factors amongst adults in the Dikgale health demographic and surveillance system (HDSS) site, Limpopo province of South Africa. PLoS One. 2016;11(2):1-18.

42. Crepinsek MK, Gordon AR, McKinney PM, Condon EM, Wilson A. Meals offered and served in US public schools: do they meet nutrient standards? J Am Diet Assoc. 2009;109(2):S31-43. Available from:. https://doi.org/10.1016/j. jada.2008.10.061.

43. Din JN, Newby DE, Flapan AD. Clinical review for a natural treatment. Bmj. 2004;328(January):30-5.

44. Costell E, Tárrega ASB. Food acceptance: the role of consumer perception and attitudes. Phys Sens Prop Lab IATACSIC, SPAIN. 2010;3(3):42-50.

45. Udofia PG, Udoudo P. J1, eyen, N. and Udoekong NS. Optimizing gari quality attributes for different groups of consumers with response surface methodology. J Agric Biotechnol Sustain Dev. 2011;3(February):28-34.

46. Kolanowski W, Wei J. Sensory quality of dairy products fortified with fish oil. Int Dairy J. 2007;17(2007):1248-53.

47. Mogendi JB, De Steur H, Gellynck X, Makokha A. Consumer evaluation of food with nutritional benefits: a systematic review and narrative synthesis. Int J Food Sci Nutr. 2016;67(4):355-71.

48. Chege CGK, Sibiko KW, Wanyama R, Jager M, Birachi E. Are consumers at the base of the pyramid willing to pay for nutritious foods? Food Policy. 2019;87(July):101745. Available from. https://doi.org/10.1016/j.foodpol.2019. 101745

\section{Publisher's Note}

Springer Nature remains neutral with regard to jurisdictional claims in published maps and institutional affiliations. 